\title{
Solubilization of struvite and biorecovery of cerium by Aspergillus niger
}

\author{
Xia Kang $^{1,2} \cdot$ Laszlo Csetenyi $^{3} \cdot$ Xiang Gao $^{4} \cdot$ Geoffrey Michael Gadd ${ }^{1,5}$ (i)
}

Received: 30 August 2021 / Revised: 25 November 2021 / Accepted: 26 November 2021 / Published online: 4 January 2022

(c) Crown 2021

\begin{abstract}
Cerium has many modern applications such as in renewable energies and the biosynthesis of nanomaterials. In this research, natural struvite was solubilized by Aspergillus niger and the biomass-free struvite leachate was investigated for its ability to recover cerium. It was shown that struvite was completed solubilized following 2 weeks of fungal growth, which released inorganic phosphate $\left(\mathrm{P}_{\mathrm{i}}\right)$ from the mineral by the production of oxalic acid. Scanning electron microscopy (SEM) showed that crystals with distinctive morphologies were formed in the natural struvite leachate after mixing with $\mathrm{Ce}^{3+}$. Energydispersive X-ray analysis (EDXA), X-ray diffraction (XRD) and Fourier-transform infrared spectroscopy (FTIR) confirmed the formation of cerium phosphate hydrate $\left[\mathrm{Ce}\left(\mathrm{PO}_{4}\right) \cdot \mathrm{H}_{2} \mathrm{O}\right]$ at lower Ce concentrations and a mixture of phosphate and cerium oxalate decahydrate $\left[\mathrm{Ce}_{2}\left(\mathrm{C}_{2} \mathrm{O}_{4}\right)_{3} \cdot 10 \mathrm{H}_{2} \mathrm{O}\right]$ at higher Ce concentrations. The formation of these biogenic $\mathrm{Ce}$ minerals leads to the removal of $>99 \% \mathrm{Ce}$ from solution. Thermal decomposition experiments showed that the biogenic Ce phosphates could be transformed into a mixture of $\mathrm{CePO}_{4}$ and $\mathrm{CeO}_{2}$ (cerianite) after heat treatment at $1000{ }^{\circ} \mathrm{C}$. These results provide a new perspective of the fungal biotransformation of soluble REE species using struvite leachate, and also indicate the potential of using the recovered REE as biomaterial precursors with possible applications in the biosynthesis of novel nanomaterials, elemental recycling and biorecovery.
\end{abstract}

\section{Key points}

- Cerium was recovered using a struvite leachate produced by A. niger.

- Oxalic acid played a major role in struvite solubilization and Ce phosphate biorecovery.

- Resulting nanoscale mineral products could serve as a precursor for Ce oxide synthesis.

Keywords Aspergillus niger $\cdot$ Rare earth elements · Struvite $\cdot$ Cerium $\cdot$ Phosphate

Geoffrey Michael Gadd

g.m.gadd@dundee.ac.uk

1 Geomicrobiology Group, School of Life Sciences, University of Dundee, Dundee DD1 5EH, UK, Scotland

2 Key Laboratory of Environmental and Applied Microbiology, CAS; Environmental Microbiology Key Laboratory of Sichuan Province, Chengdu Institute of Biology, Chinese Academy of Sciences, Chengdu 610041, China

3 Concrete Technology Group, Department of Civil Engineering, University of Dundee, Dundee, DD1 4HN, UK, Scotland

4 School of Chemistry, University of St Andrews, St Andrews KY16 9ST, Scotland, UK

5 State Key Laboratory of Heavy Oil Processing, Beijing Key Laboratory of Oil and Gas Pollution Control, College of Chemical Engineering and Environment, China University of Petroleum, 18 Fuxue Road, Changping District, Beijing 102249, China

\section{Introduction}

Cerium (Ce) is classified as one of the light rare earth elements (REE) in the lanthanide series and bears similar physical and chemical properties to lanthanum (Massari and Ruberti 2013). The predominant source of cerium is monazite ore $\left[(\mathrm{Ce}, \mathrm{La}, \mathrm{Nd}) \mathrm{PO}_{4}\right]$, which contains $40-50 \%$ cerium on average (Kumari et al. 2015). It is estimated that by the year 2030, the global annual production of Ce will be 186.54 kilotonnes, which is the highest among all the other REE and accounts for $40.5 \%$ of total REE production (Moss et al. 2013). Cerium compounds are traditionally used in components of cigarette lighter flints, petroleum cracking catalysts, energy-efficient light sources and solid oxide fuel cells (SOFC) (Li et al. 2000; van Krevel et al. 2002; Martínez-Arias et al. 2005; Haque et al. 2014). More recently, 
nanoscale cerium compounds have been synthesized and new applications discovered in biomedical sciences such as bioimaging, biosensing and therapeutic nanomaterials (Babu et al. 2010; Siposova et al. 2019; Singh et al. 2020). Therefore, as more novel applications are emerging, cerium will be one of the most promising rare earth elements that deserves attention.

Biomineralization refers to the biologically mediated formation of new minerals and is an indispensable step in geomicrobial processes (Verrecchia et al. 1993; Adeyemi and Gadd 2005; Gadd 2010, 2017). It is well known that biomineralization can occur as a result of interactions between microbes and metal species in both solid and aqueous forms (Francis 1998; Rawlings et al. 2003). Microbial biomineralization has been taken advantage of in recent years because of its environmentally friendly nature and cost-effectiveness, and therefore has potential applications for the removal of environmental pollutants and the recovery of precious metals from wastes (Liang and Gadd 2017; Yang et al. 2019; Li et al. 2020a,b; Xu et al. 2020). Geoactive fungi play an important role in the biomineralization of a broad range of minerals and have been investigated for their potential in the recycling of elements and biosynthesis of new biomaterials (Gadd 2007; Liang and Gadd 2017; Kang et al. 2020, 2021). The fundamental mechanisms behind fungal biomineralization involve the production of metabolites such as oxalate and carbon dioxide, or the release of ligands like carbonates and phosphates from organic and inorganic sources, as well as proteins and enzymes that can directly interact with the metal/mineral (Gadd 2007, 2010; Li et al. 2014; Kumari et al. 2016; Dhami et al. 2017; Fomina et al. 2007; Liu et al. 2019; Kirtzel et al. 2020; Kang et al. 2020, 2021; Mendes et al. 2021a,b; Liu et al. 2021).

Phosphates play an important role in the biogeochemical cycles of elements. Common P-bearing minerals such as phosphate rocks and apatites (Ca-phosphates) can be solubilized by phosphate-solubilizing microorganisms (Bolan et al. 1994; Zhenghua et al. 2001; Mendes et al. 2021a,b). Some fungal species, e.g. Aspergillus niger and Paecilomyces javanicus, were able to precipitate soluble U(IV) and $\mathrm{Pb}$ when supplemented with an organic $\mathrm{P}$ source (glycerol2-phosphate), suggesting that this process could be exploited for biorecovery and bioremediation (Liang et al. 2015, 2016a, b; Rhee et al. 2016). Struvite $\left(\mathrm{MgNH}_{4} \mathrm{PO}_{4} \cdot 6 \mathrm{H}_{2} \mathrm{O}\right)$ is commonly found in sewage treatment plants and sludge handling facilities, causing blockages to pipelines (Doyle and Parsons 2002; Wang et al. 2018). A large amount of research has concentrated on the recovery of $\mathrm{P}$ and $\mathrm{Mg}$ by struvite crystallization (Le Corre et al. 2009; Liang et al. 2019). In contrast, few studies have ventured the idea of solubilizing struvite and recycling $\mathrm{P}$ and $\mathrm{Mg}$ as other useful materials through microbial processes (Hernández Jiménez et al. 2020; Kecskésová et al. 2020). The solubility product of struvite is $10^{-13.29}<K_{\mathrm{sp}}<10^{-13.08}$, which is much greater than that of calcium phosphate $\left(K_{\mathrm{sp}}=1.3 \times 10^{-26}\right)$, and it has been confirmed that acid-producing $A$. niger is able to solubilize both natural and synthetic struvite releasing high amounts of P into the leachate (Hanhoun et al. 2011; Suyamud et al. 2020; Ferrier et al. 2021). Cerium phosphate nanotubes and nanowires can be synthesized, using complex chemical methods, which exhibit optical, photoprotective and other properties (Bu et al. 2004; Tang et al. 2005; Xing et al. 2006; de Lima and Serra 2013). However, there is a lack of research on the biosynthesis of this potentially useful material through a microbial process.

The present study offers insights into and provides fundamental knowledge about the interactions between $A$. niger and cerium with an aim to explore novel approaches for biorecovery of REE as phosphate biominerals using a biomass-free struvite leachate. The work also contributes to further understanding of the extracellular synthesis of biomaterials from a fungal system.

\section{Methods and materials}

\section{Microorganism and culture medium}

A wild-type strain of Aspergillus niger (ATCC 1015), which was routinely maintained on malt extract agar (MEA) (Lab $\mathrm{M}$ Limited, Bury, UK) in the dark at $25{ }^{\circ} \mathrm{C}$, was used in the present study. Modified Czapek-Dox medium (MCD) consisted of $\left(1^{-1}\right.$ Milli-Q water) D-glucose $30 \mathrm{~g}, \mathrm{NaNO}_{3}$ $2 \mathrm{~g}, \mathrm{Na}_{2} \mathrm{HPO}_{4} 1 \mathrm{~g}, \mathrm{MgSO}_{4} \cdot 7 \mathrm{H}_{2} \mathrm{O} 0.5 \mathrm{~g}, \mathrm{KCl} 0.5 \mathrm{~g}$ and $\mathrm{FeSO}_{4} \cdot 7 \mathrm{H}_{2} \mathrm{O} 0.01 \mathrm{~g}$. The final $\mathrm{pH}$ was adjusted to $\mathrm{pH} 5.5$ with sterile $1 \mathrm{M} \mathrm{HCl}$ prior to autoclaving for $15 \mathrm{~min}$ at $115^{\circ} \mathrm{C}$.

\section{Solubilization of struvite}

A natural struvite sample was used to provide P-rich biomass-free spent culture medium for the precipitation of Ce phosphate. Struvite fragments were obtained from the operating site (Exeter, UK) of Veolia Water Outsourcing (London, UK) and pulverised using a pestle and mortar. A. niger was initially inoculated on MEA plates and grown for several days until a luxuriant growth state was reached. A spore suspension was then made using the following procedure: sterile $0.1 \%(\mathrm{v} / \mathrm{v})$ Tween 80 was poured on the fungal colony, mixed well by pipetting multiple times, filtered through micro-pored $(40 \mu \mathrm{m})$ sterile muslin cloth (Henry Simon Limited, Cheshire, UK) and washed three times using sterile Milli-Q water by centrifugation $(2553 \mathrm{~g}$, $30 \mathrm{~min}$ ). The number of spores in the suspension was determined using a Neubauer-improved counting chamber (Paul Marienfeld GmbH \& Co. KG, Lauda-Königshofen, 
Germany). The suspension was diluted to desired concentration using sterile Milli-Q water before use. The struvite sample was oven-sterilized at $105^{\circ} \mathrm{C}$ for $48 \mathrm{~h}$ and added at $1 \%(\mathrm{w} / \mathrm{v}$ ) to $500 \mathrm{ml}$ Erlenmeyer flasks containing $200 \mathrm{ml}$ MCD medium, which were inoculated with an appropriate amount of $A$. niger spore suspension resulting in $1 \times 10^{6}$ spores $\mathrm{ml}^{-1}$ final concentration. Flasks without inoculation served as the control. All the flasks were maintained in a shaking incubator (GE Healthcare, Buckinghamshire, UK) for 14 days in the dark $\left(125 \mathrm{rpm}, 25^{\circ} \mathrm{C}\right)$. An aliquot of approximately $0.5 \mathrm{ml}$ culture supernatant was taken every other day for $\mathrm{pH}$ measurement using a flat-tipped $\mathrm{pH}$ probe (VWR International, Lutterworth, England, UK) and other analyses.

\section{Biorecovery of Ce phosphate}

The biomass-free spent liquid culture medium was obtained by vacuum pump-filtration through a Whatman filter paper (GE Healthcare, Buckinghamshire, UK). Metal cations in the filtered medium were removed using $A G{ }^{\circledR}$ $50 \mathrm{~W}-\mathrm{X} 8$ cation exchange resin (20-50 mesh, in hydrogen form) (Bio-Rad Laboratories, CA, USA) which efficiently replaces all metal ions with $\mathrm{H}^{+}$. This was achieved by adding $0.5 \mathrm{~g}$ resin into $5 \mathrm{ml}$ biomass-free culture medium and maintaining on a roller mixer (Stuart Equipment, Stone, Staffordshire, UK) for $24 \mathrm{~h}$ at ambient temperature. After metal cations were removed, the $\mathrm{pH}$ of the biomass-free culture medium was adjusted to $\mathrm{pH} 7.5$ using $4 \mathrm{M} \mathrm{NaOH}$ and filtered again using a $0.25 \mu \mathrm{m}$ Minisart syringe filter (Sartorius Stedim Biotech GmbH, Göttingen, Germany) before use. Biorecovery experiments were performed using a $10-\mathrm{ml}$ reaction system in $15 \mathrm{ml}$ centrifuge tubes by mixing biomass-free liquid culture medium with sterile $\mathrm{CeCl}_{3}$ at the following final concentrations: 5, 20, 40 and $50 \mathrm{mM} \mathrm{Ce}^{3+}$, and incubating on a roller mixer (Stuart Equipment, Stone, Staffordshire, UK) for $24 \mathrm{~h}$ at room temperature. The phosphate biominerals were collected and washed three times using Milli-Q water, and the supernatant $\mathrm{pH}$ was measured. Each treatment was performed in triplicate.

\section{Harvest, desiccation and weighing of biominerals}

The biominerals were harvested and washed three times by centrifugation ( $2553 \mathrm{~g}, 30 \mathrm{~min}$ ) using a J6-MI highcapacity centrifuge (Beckman Coulter, High Wycombe, UK). All biominerals were dried for at least 2 weeks at room temperature in a desiccator filled with Chameleon silica gel (VWR International Ltd., Lutterworth, England, UK). The yield of biominerals was measured by weighing using a Galaxy HR-150A analytical balance (A\&D Company, Tokyo, Japan).

\section{Determination of cerium}

Ce concentrations in supernatants after liquid reactions were measured using the Arsenazo III colorimetric method (Hogendoorn et al. 2018). This was achieved by mixing $1 \mathrm{ml}$ of an appropriately diluted sample with $1 \mathrm{ml} 0.02 \%(\mathrm{w} / \mathrm{v}$ ) Arsenazo III solution (Sigma-Aldrich, St. Louis, USA) and $8 \mathrm{ml} \mathrm{pH} 2.8$ potassium hydrogen phthalate buffer. After $10 \mathrm{~min}$, the $\mathrm{OD}_{658 \mathrm{~nm}}$ of mixture was measured using an Ultrospec 2100 pro spectrophotometer (Biochrom Ltd., Holliston, MA, USA). Ce concentrations in the liquid samples were calculated according to a standard curve created using the following concentrations: $0,0.1,0.2,0.3,0.5$ and $1.0 \mathrm{mg}^{-1}$ REE.

\section{Determination of oxalic acid}

The determination of oxalic acid in the culture supernatant was carried out using an UltiMate 3000 high-performance liquid chromatography (HPLC) system (Dionex, San Diego, CA, USA) fitted with an Aminex HPX-87H column in connection with a Micro-Guard cation $\mathrm{H}^{+}$refill cartridge (BioRad Laboratories, CA, USA). Samples were prepared by appropriately diluting the original liquid. Standard solutions contained the following acids: 5, 10, 15 and $20 \mathrm{mM}$ citric acid (Sigma-Aldrich, St. Louis, USA); 1, 2, 3 and $4 \mathrm{mM}$ oxalic acid (Sigma-Aldrich, St. Louis, USA). All samples and standards were filtered through a $0.25-\mu \mathrm{m}$ Minisart syringe filter (Sartorius Stedim Biotech GmbH, Göttingen, Germany) and pipetted into HPLC certified vials (SigmaAldrich, St. Louis, USA). The mobile phase was $5 \mathrm{mM}$ $\mathrm{H}_{2} \mathrm{SO}_{4}$, which was prepared using HPLC LiChropur $98 \%$ sulfuric acid (Merck KGaA, Darmstadt, Germany) and degassed by pump-filtration through a $0.45-\mu \mathrm{m}$ Whatman cellulose nitrate membrane filter (GE Healthcare, Buckinghamshire, UK). The parameters for the HPLC system were as follows: flow rate at $0.6 \mathrm{ml} \mathrm{min} \mathrm{mi}^{-1}$, column temperature at $35^{\circ} \mathrm{C}$, sample injection volume $20 \mu \mathrm{l}$ and wavelength of the UV detector $210 \mathrm{~nm}$. The concentration of organic acids was automatically calculated by the Chromeleon 6.8 Chromatography Data System Software (Thermo Fisher Scientific, MA, USA) at default settings. The measurements were performed in at least three replicates.

\section{EDXA, SEM, XRD, XRF, TGA and FTIR}

Dried mineral samples were mounted on adhesive carbon tape on $25 \mathrm{~mm} \times 5 \mathrm{~mm}$ aluminium electron microscopy stubs (Agar Scientific Ltd., Essex, UK) before being examined using an energy-dispersive X-ray spectroscopy analysis (EDXA) system (Oxford Inca, Abingdon, Oxon, UK) operating in conjunction with a Jeol JSM-7400F field emission scanning electron microscope (JEOL Ltd., Tokyo, Japan) at 
an accelerating voltage of $15 \mathrm{kV}$ for $100 \mathrm{~s}$. Samples for scanning electron microscopy (SEM) were coated with a layer of $10 \mathrm{~nm}$ gold and platinum using a Cressington 208HR sputter coater (Ted Pella, Redding, CA, USA) prior to examination using a field emission scanning electron microscope (Jeol JSM7400F) operating at an accelerating voltage of $5 \mathrm{kV}$. X-ray diffraction (XRD) was performed using a Hiltonbrooks X-ray diffractometer (HiltonBrooks Ltd., Crewe, UK) furnished with a monochromatic $\mathrm{CuK} \alpha$ source and curved graphite, single-crystal chronometer $(30 \mathrm{~mA}$, $40 \mathrm{kV}$ ). To prepare for XRD, samples were ground to a fine powder using a ceramic mortar and pestle and compacted tightly on the reverse side of an aluminium specimen holder $(15 \times 20 \times 2 \mathrm{~mm})$ held against a glass slide. The back cover was then snapped into place and the glass slide was removed from the holder. Duplicate samples were analyzed over the range $3-60^{\circ} 2 \theta$ at a scan rate of one degree $\mathrm{min}^{-1}$ in 0.1 degree increments. X-ray fluorescence (XRF) spectroscopy was carried out using a Philips Zetium PW5400 sequential spectrometer with an RhK $\alpha$ source (Malvern Panalytical, Malvern, UK), and calibrated with certified standard materials. The samples were placed in a 32-mm-diameter pellet mould, and were compacted under loads of $75 \mathrm{kN}$ for $5 \mathrm{~min}$ and $150 \mathrm{kN}$ for a further $10 \mathrm{~min}$ and then transferred to a specimen cup that had a 27 -mm-diameter viewing aperture. The results are expressed as oxides. Thermal decomposition of the biominerals for thermogravimetric analysis (TGA) was carried out using a NETZSCH STA 409PC TG/DTG/ DTA analyser fitted with a SiC furnace (NETZSCH Group, Selb, Germany). Small amounts ( $<100 \mathrm{mg}$ ) of samples were heated to $1000{ }^{\circ} \mathrm{C}$ at a heating rate of $10 \mathrm{~K} \mathrm{~min}^{-1}$ using dry $\mathrm{N}_{2}$ as a purge gas at a flow rate of $100 \mathrm{~cm}^{3} \mathrm{~min}^{-1}$ and maintained at $1000{ }^{\circ} \mathrm{C}$ until constant weight. Fourier-transform infrared spectroscopy (FTIR) was employed for further accurate identification of nanoscale biomineral samples. Dried samples were ground to a fine powder using a pestle and mortar for the analysis, which was carried out using an IRAffinity-1S compact Fourier-transform infrared spectrophotometer (Shimadzu Corporation, Kyoto, Japan). The wavenumber was measured at a range of $400-4000 \mathrm{~cm}^{-1}$ (wavelengths 2.5 to $25 \mu \mathrm{m}$ ) at a resolution of $1 \mathrm{~cm}^{-1}$.

\section{Results}

\section{Mineral profile and solubilization of struvite}

XRF showed that the natural struvite sample was mainly composed of $\mathrm{P}\left(48.782 \% \mathrm{P}_{2} \mathrm{O}_{5}\right)$ and $\mathrm{Mg}(24.711 \% \mathrm{MgO})$ (Table 1). Most of the other elements detected existed in trace amounts at $<1 \%$. XRD analysis of the struvite samples used in these experiments showed that the natural struvite
Table 1 Elemental composition (\% by mass) of the struvite sample determined using X-ray fluorescence

\begin{tabular}{ll}
\hline Element* & Natural struvite \\
\hline $\mathrm{Fe}_{2} \mathrm{O}_{3}$ & 0.154 \\
$\mathrm{CaO}$ & 1.557 \\
$\mathrm{~K}_{2} \mathrm{O}$ & 0.173 \\
$\mathrm{P}_{2} \mathrm{O}_{5}$ & 48.782 \\
$\mathrm{MgO}$ & 24.711 \\
$\mathrm{Al}_{2} \mathrm{O}_{3}$ & 0.123 \\
$\mathrm{Cl}$ & 0.012 \\
$\mathrm{SiO}_{2}$ & 0.214 \\
$\mathrm{SO}_{3}$ & 0.071 \\
$\mathrm{MnO}$ & 0.141 \\
$\mathrm{Co}$ & 0.007 \\
$\mathrm{Sum}$ & 75.970 \\
\hline
\end{tabular}

*Some elements are expressed as oxides

Typical values are from several measurements

pattern (Fig. 1A) matched with the reference minerals of struvite $\left(\mathrm{NH}_{4} \mathrm{MgPO}_{4} \cdot 6 \mathrm{H}_{2} \mathrm{O}\right)$ (PDF card number: 15-762) (Fig. 1B) and dittmarite $\left(\mathrm{NH}_{4} \mathrm{MgPO}_{4} \cdot \mathrm{H}_{2} \mathrm{O}\right)(\mathrm{PDF}$ card number: 20-663) (Fig. 1C).

During 14-day leaching of $1 \%(\mathrm{w} / \mathrm{v})$ struvite-containing samples using $A$. niger in liquid MCD medium, oxalic acid, medium $\mathrm{pH}$ and inorganic phosphate $\left(\mathrm{P}_{\mathrm{i}}\right)$ concentration were measured. After the sixth day of incubation, oxalic acid was detected in all liquid samples at concentrations of $9.18 \pm 1.90 \mathrm{mM}$ and $26.77 \pm 0.04 \mathrm{mM}$ for the natural struvite leachate and struvite-free culture, respectively (Fig. 2A). The concentration of oxalic acid in both supernatants followed an increasing trend until the $14^{\text {th }}$ day at $26.49 \pm 3.43 \mathrm{mM}$ (natural struvite leachate) and $74.57 \pm 1.07 \mathrm{mM}$ (struvitefree control). A significant difference in the oxalic acid concentration was observed between the struvite leachate and the control, and the struvite leachate generally contained $50 \%$ lower amounts of oxalic acid than the control. As dissolution of struvite occurred, the release of soluble phosphate was detected on the $2^{\text {nd }}$ day of incubation (Fig. 2B). The concentration of soluble $\mathrm{P}_{\mathrm{i}}$ increased, reached a plateau on the $6^{\text {th }}$ day and ended at $51.37 \pm 0.59 \mathrm{mM}$ for the natural struvite leachate. The medium $\mathrm{pH}$ showed a constant declining trend throughout the incubation period and ended at $\mathrm{pH}$ $2.46 \pm 0.11$ and $\mathrm{pH} 1.64 \pm 0.02$ for the natural struvite leachate and the struvite-free control, respectively (Fig. 2C). The medium $\mathrm{pH}$ of the struvite leachate was always significantly higher than the struvite-free control. Upon completion of the leaching process, the A. niger biomass yield was

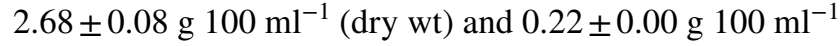
(dry wt) for the natural struvite leachate and struvite-free control, respectively (Fig. 2D). An apparent difference was 
Fig. 1 XRD patterns of (A) natural struvite. Shown below the experimental patterns are (B) reference pattern of the standard mineral $\mathrm{NH}_{4} \mathrm{MgPO}_{4} \cdot 6 \mathrm{H}_{2} \mathrm{O}$ (card number: 15-762) and (C) reference pattern of standard $\mathrm{NH}_{4} \mathrm{MgPO}_{4} \cdot \mathrm{H}_{2} \mathrm{O}$ (card number: 20-663) from the Powder Diffraction File (PDF) database. Typical patterns are shown from one of several determinations

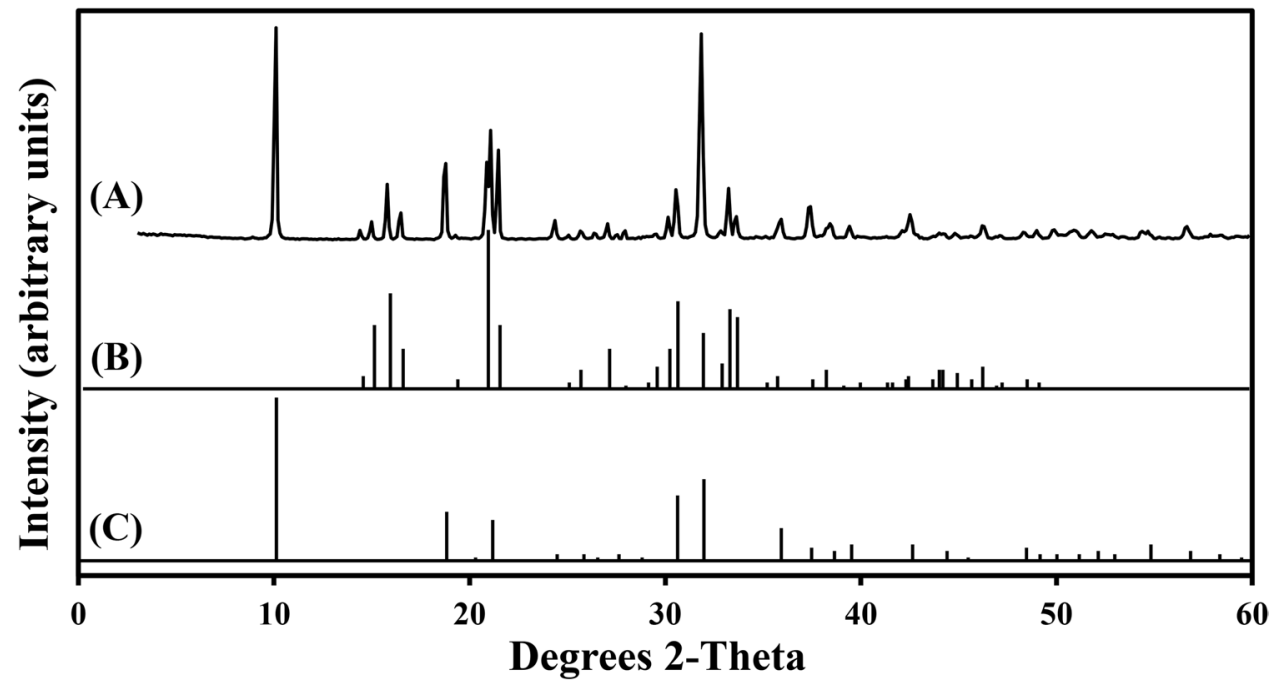

(A)

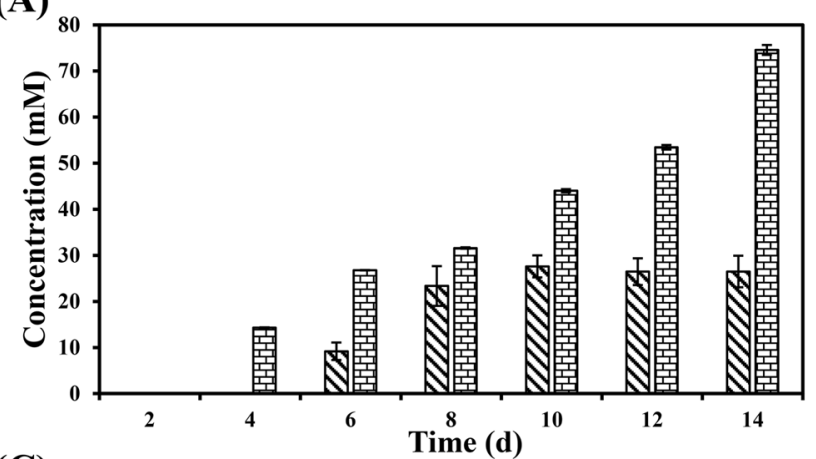

(C)

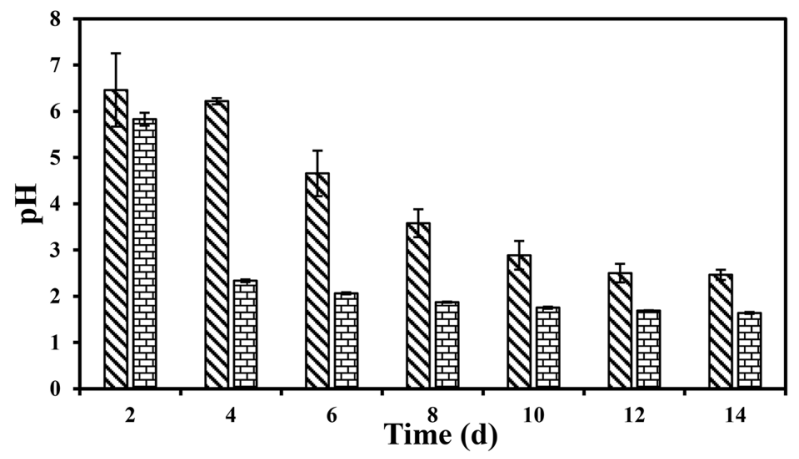

Fig. 2 (A) Oxalic acid concentration and (C) supernatant $\mathrm{pH}$ in liquid MCD media inoculated with A. niger and supplemented with (diagonal-patterned bar) $1 \%$ natural struvite and (brick-patterned bar) without struvite during 14-day shake incubation at $25^{\circ} \mathrm{C}$ and $125 \mathrm{rpm}$ in the dark. (B) $\mathrm{P}_{\mathrm{i}}$ concentration in liquid $\mathrm{MCD}$ media inoculated with

found between these two samples. An examination of the fungal pellets revealed that MCD medium supplemented with natural struvite led to more exuberant growth of $A$. niger than the struvite-free control.
(D)

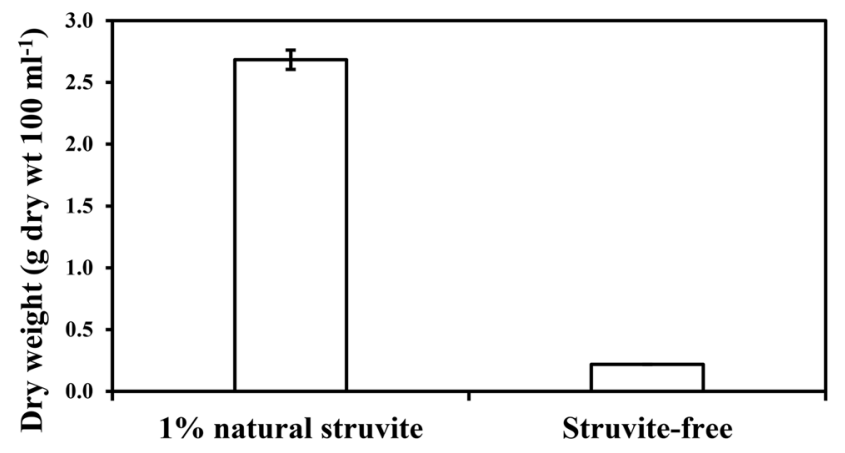

A. niger and supplemented with (solid/black circle) $1 \%$ natural struvite and (solid/black square) without struvite under the same conditions. (D) Biomass yield of A. niger after 14-day incubation under the same conditions. Data are averages of at least three replicates and error bars show the standard error of the mean

\section{Cerium biorecovery using struvite leachate}

The filtered and $\mathrm{pH}$-adjusted struvite leachate was used to recover $\mathrm{Ce}$ from $\mathrm{CeCl}_{3}$ (final concentrations of 5, 20, 40 and

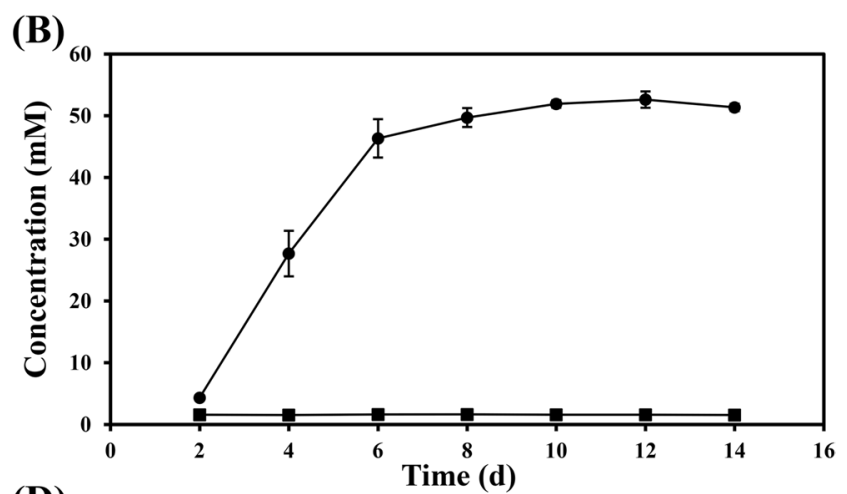


(A)

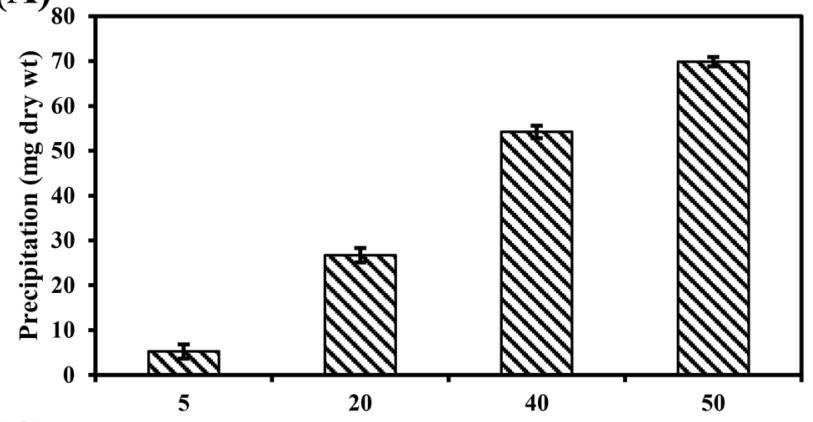

(C)

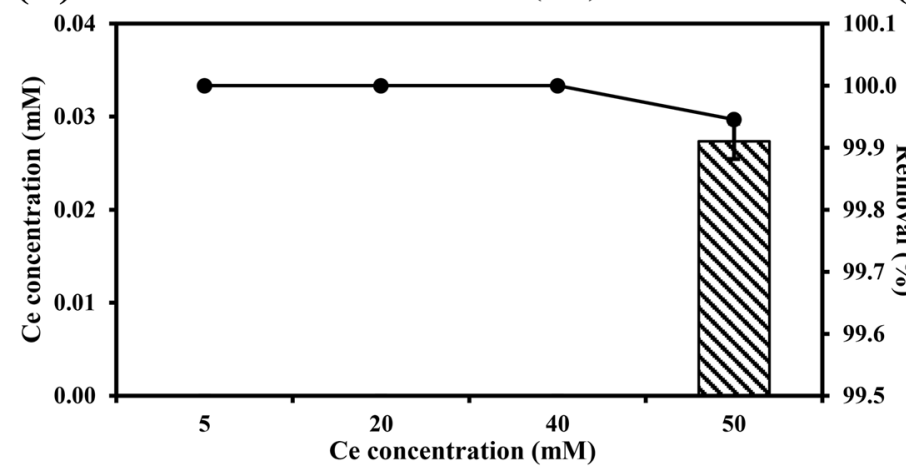

(B)

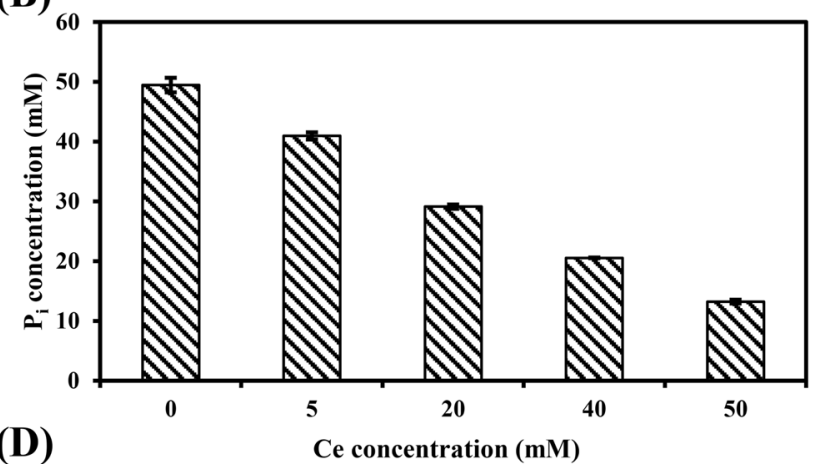

(D)

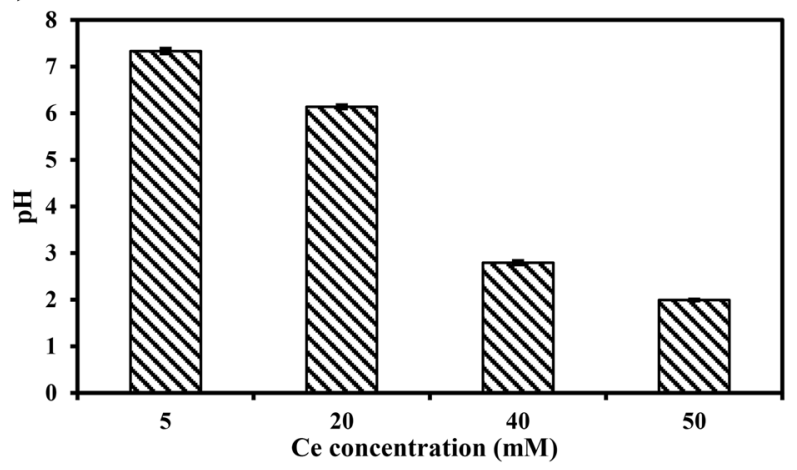

Fig. 3 (A) Biomineral yield, (B) supernatant $\mathrm{P}_{\mathrm{i}}$ concentration, (C) supernatant $\mathrm{Ce}$ concentration and $(\mathbf{D})$ supernatant $\mathrm{pH}$ after reaction of $5 \mathrm{mM}, 20 \mathrm{mM}, 40 \mathrm{mM}$ and $50 \mathrm{mM} \mathrm{CeCl}_{3}$ (final concentration) with natural struvite leachate for $24 \mathrm{~h}$ at room temperature on a roller mixer. The leachate was obtained from a 14-day shake incubation of

$50 \mathrm{mM}$ ) and this resulted in a white precipitate after mixing. The amount of biominerals gradually increased as $\mathrm{CeCl}_{3}$ of higher concentration was added to the leachate of natural struvite (Fig. 3A). The total concentration of soluble $P_{i}$ in the struvite leachate was significantly reduced as the concentration of $\mathrm{CeCl}_{3}$ increased (Fig. 3B). The concentration of $\mathrm{P}_{\mathrm{i}}$ left in the leachate after mixing $50 \mathrm{mM} \mathrm{CeCl}_{3}$ with the struvite leachate was $13.22 \pm 0.31 \mathrm{mM}$. $\mathrm{Ce}^{3+}$ was completely removed $(100 \%)$ from the leachate of natural struvite after mixing with 5, 20 and $40 \mathrm{mM} \mathrm{CeCl}_{3}$, while $99.95 \% \mathrm{Ce}^{3+}$ was removed after mixing with $50 \mathrm{mM} \mathrm{CeCl}_{3}$ (Fig. 3C). The amount of $\mathrm{Ce}^{3+}$ left after reaction with $50 \mathrm{mM} \mathrm{CeCl}_{3}$ was only $27.34 \pm 1.91 \mu \mathrm{M}$ in the natural struvite leachate. A significant drop of supernatant $\mathrm{pH}$ with the increasing amount of added $\mathrm{CeCl}_{3}$ was recorded for the leachate (Fig. 3D).

\section{Morphologies and identification of biominerals}

SEM examination showed that the biominerals formed after mixing the struvite leachate with 5 and $20 \mathrm{mM} \mathrm{CeCl}_{3}$ were aggregates of nanoparticles with no distinguishable boundaries (Fig. 4A and B). Slender cuboid crystals measuring $\sim 20 \mu \mathrm{m}$ long and $\sim 2 \mu \mathrm{m}$ wide along with the amorphous biominerals were observed in the precipitate formed in the
A. niger in liquid MCD medium supplemented with $1 \%$ natural struvite. Solid/black circle: $\%$ removal of $\mathrm{Ce}^{3+}$ by $1 \%$ natural struvite leachate. Data are averages of at least three replicates and error bars show the standard error of the mean. Error bars are not shown when smaller than the dimensions of the symbols

natural struvite leachate after mixing with $40 \mathrm{mM} \mathrm{CeCl}_{3}$ (Fig. 4C). Large aggregates of tabloid crystals of similar size were precipitated after reaction of the natural struvite leachate with $50 \mathrm{mM} \mathrm{CeCl}_{3}$ (Fig. 4D). EDXA revealed that the amorphous biominerals formed at all concentrations of $\mathrm{CeCl}_{3}$ in the struvite leachate consisted of $\mathrm{C}, \mathrm{O}, \mathrm{Ce}$ and high amounts of $\mathrm{P}$ (Fig. 5A), whereas the crystals were composed of very low amounts of $\mathrm{P}$ as well as similar levels of the other elements as in the amorphous biominerals (Fig. 5B).

XRD showed that the patterns of all the tested minerals were similar with a high background noise. Peaks at 13.14, $22.54,27.64,27.84,29.45,30.49$ and 30.75 degrees 2-theta were identified and assigned to standard reference patterns. XRD patterns of the biominerals resulting from mixing the biomass-free struvite leachate with $20 \mathrm{mM} \mathrm{CeCl}_{3}$ (Fig. 6a) exhibited similarities with a match to only $\mathrm{Ce}\left(\mathrm{PO}_{4}\right) \cdot \mathrm{H}_{2} \mathrm{O}$ (Mooney 1950; Barrera-Villatoro et al. 2017) (Fig. 6d). The patterns of the biominerals formed by mixing the biomassfree struvite leachate with $50 \mathrm{mM} \mathrm{CeCl}_{3}$ (Fig. 6b) exhibited distinguishable peaks with a match to standard $\mathrm{Ce}\left(\mathrm{PO}_{4}\right) \cdot \mathrm{H}_{2} \mathrm{O}$ (Fig. 6d) and $\mathrm{Ce}_{2}\left(\mathrm{C}_{2} \mathrm{O}_{4}\right)_{3} \cdot 10 \mathrm{H}_{2} \mathrm{O}$ (Fig. 6c). Rietveld refinement analysis further revealed that the biominerals formed at $20 \mathrm{mM} \mathrm{CeCl}_{3}$ contained $100 \% \mathrm{Ce}\left(\mathrm{PO}_{4}\right) \cdot \mathrm{H}_{2} \mathrm{O}$ (Table 2). The biominerals formed by mixing $50 \mathrm{mM} \mathrm{CeCl}{ }_{3}$ with natural 
Fig. 4 SEM images of biominerals formed after the reaction of natural struvite leachate with (A) $5 \mathrm{mM}$, (B) $20 \mathrm{mM}$, (C) $40 \mathrm{mM}$ and (D) $50 \mathrm{mM} \mathrm{CeCl}_{3}$ (final concentration) for $24 \mathrm{~h}$ at room temperature. Scale bars: (A and B) $1 \mu \mathrm{m},(\mathrm{C}$ and D) $10 \mu \mathrm{m}$. Typical images are shown from several similar examinations
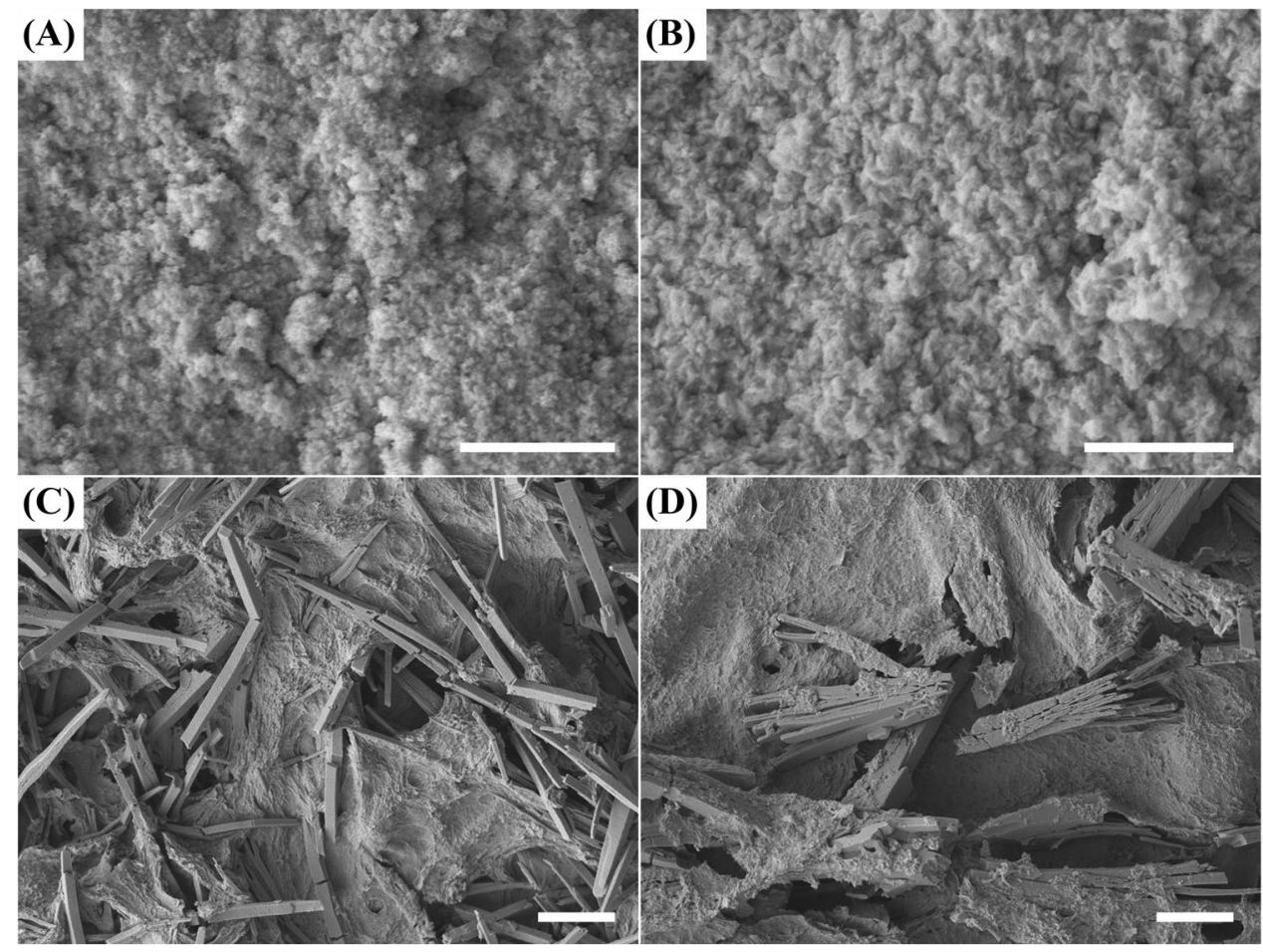

Fig. 5 EDXA of (A) amorphous biominerals and $(\mathbf{B})$ crystalline biominerals resulting from reaction of natural struvite leachate with different concentrations of $\mathrm{CeCl}_{3}$. Typical spectra are shown from several similar determinations

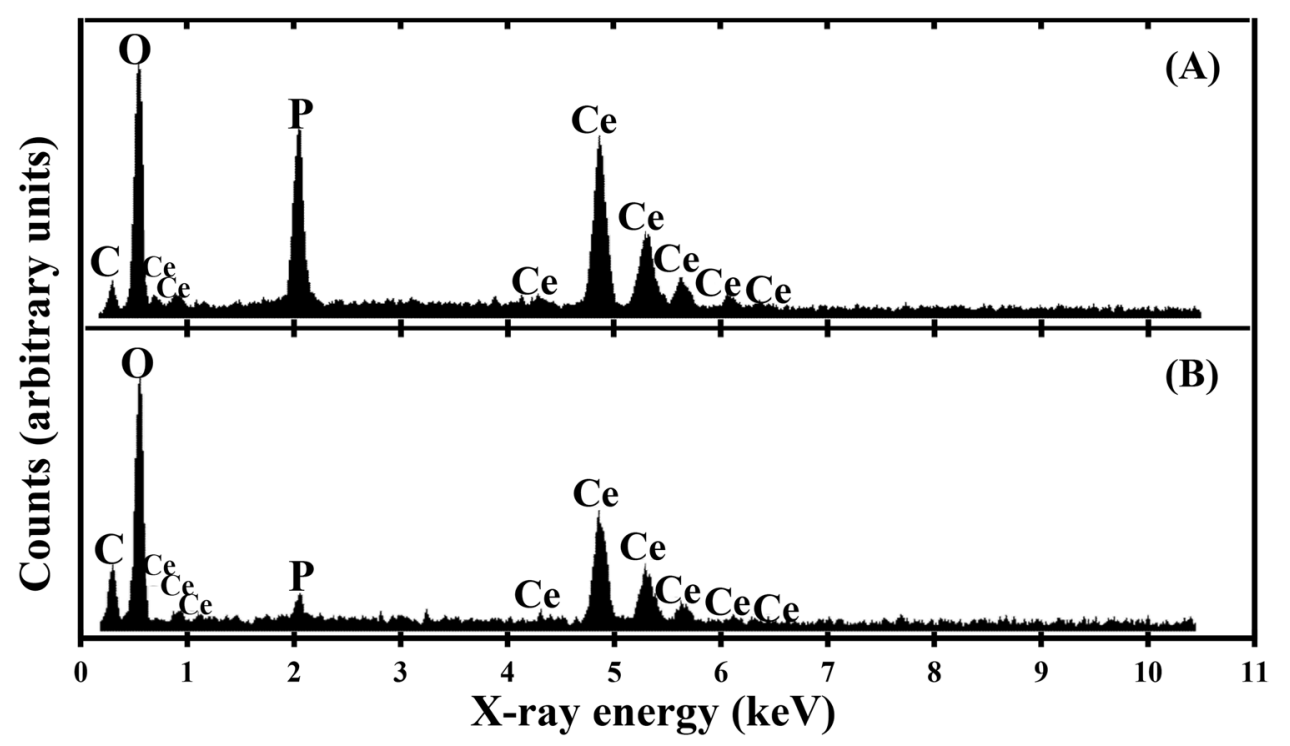

struvite leachate were composed of $78.3 \% \mathrm{Ce}\left(\mathrm{PO}_{4}\right) \cdot \mathrm{H}_{2} \mathrm{O}$ and $21.7 \% \mathrm{Ce}_{2}\left(\mathrm{C}_{2} \mathrm{O}_{4}\right)_{3} \cdot 10 \mathrm{H}_{2} \mathrm{O}$.

After thermal treatment at $1000{ }^{\circ} \mathrm{C}$, minerals precipitated at both concentrations showed improved crystallinity with sharp peaks and a very low noise base (Fig. 7a and b). The biomineral sample resulting from mixing natural struvite leachate with $20 \mathrm{mM} \mathrm{CeCl}_{3}$ showed a match to standard $\mathrm{CePO}_{4}$ (Fig. 7c), while that obtained from mixing natural struvite leachate with $50 \mathrm{mM} \mathrm{CeCl}_{3}$ comprised $\mathrm{CePO}_{4}$ and $\mathrm{CeO}_{2}$ (cerianite) (Fig. 7d). Rietveld refinement analysis revealed that the biominerals precipitated using natural struvite leachate at $20 \mathrm{mM} \mathrm{CeCl}_{3}$ contained $100 \% \mathrm{CePO}_{4}$ (Table 2). The sample formed using natural struvite leachate at $50 \mathrm{mM} \mathrm{CeCl}_{3}$ was composed of $90.4 \% \mathrm{CePO}_{4}$ and $9.6 \%$ $\mathrm{CeO}_{2}$ (Table 2).

Thermogravimetric analysis (TGA) showed that the biomineral samples precipitated at $20 \mathrm{mM} \mathrm{CeCl}_{3}$ using the natural struvite leachate had a $16.4 \%$ mass-loss event at $153.1^{\circ} \mathrm{C}$ according to the thermogravimetry (TG) and derivative thermogravimetry (DTG) curves (Fig. 8A). The DTG 
Fig. 6 XRD patterns of the minerals formed after mixing of natural struvite leachate with (a) $20 \mathrm{mM}$ and (b) $50 \mathrm{mM} \mathrm{CeCl}_{3}$ for $24 \mathrm{~h}$ at room temperature. (c) Standard reference pattern of the mineral $\mathrm{Ce}_{2}\left(\mathrm{C}_{2} \mathrm{O}_{4}\right)_{3} \cdot 10 \mathrm{H}_{2} \mathrm{O}$ (PDF card number: 20-268). (d) Standard reference pattern of the mineral $\mathrm{Ce}\left(\mathrm{PO}_{4}\right) \cdot \mathrm{H}_{2} \mathrm{O}$. Typical patterns are shown from one of several determinations

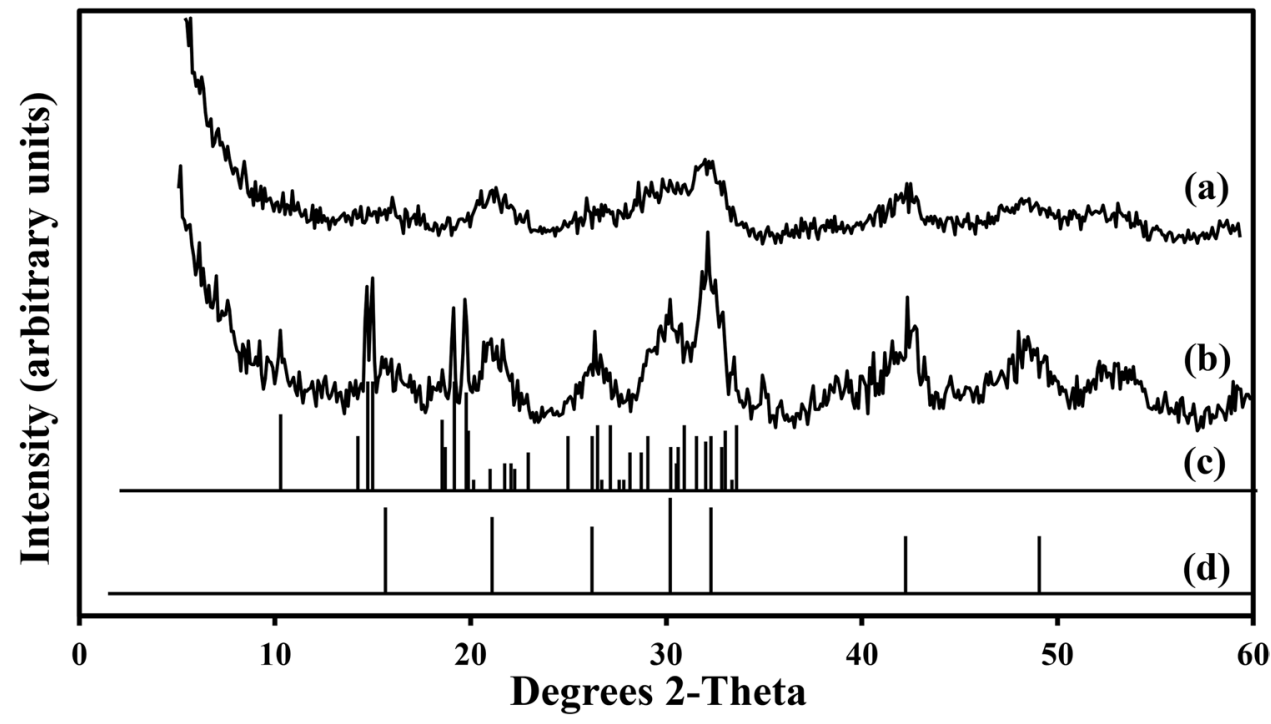

Table 2 Quantification of the mineral phases in the samples through the Rietveld refinement of XRD data

\begin{tabular}{|c|c|c|c|}
\hline \multicolumn{2}{|l|}{ Treatment } & \multicolumn{2}{|c|}{ Mineral composition } \\
\hline & & $\mathrm{Ce}\left(\mathrm{PO}_{4}\right) \cdot \mathrm{H}_{2} \mathrm{O}$ & $\mathrm{Ce}_{2}\left(\mathrm{C}_{2} \mathrm{O}_{4}\right)_{3} \cdot 10 \mathrm{H}_{2} \mathrm{O}$ \\
\hline \multirow[t]{3}{*}{ Before TG-DTG } & $\mathrm{N}+20 \mathrm{mM} \mathrm{Ce}$ & $100 \%$ & Undetected \\
\hline & $\mathrm{N}+50 \mathrm{mM} \mathrm{Ce}$ & $78.3 \%$ & $21.7 \%$ \\
\hline & & $\mathrm{CePO}_{4}$ & $\mathrm{CeO}_{2}$ \\
\hline \multirow[t]{2}{*}{ After TG-DTG } & $\mathrm{N}+20 \mathrm{mM} \mathrm{Ce}$ & $100 \%$ & Undetected \\
\hline & $\mathrm{N}+50 \mathrm{mM} \mathrm{Ce}$ & $90.4 \%$ & $9.6 \%$ \\
\hline
\end{tabular}

$\mathrm{N}=$ biomass-free natural struvite leachate

Typical values are shown from one of several determinations

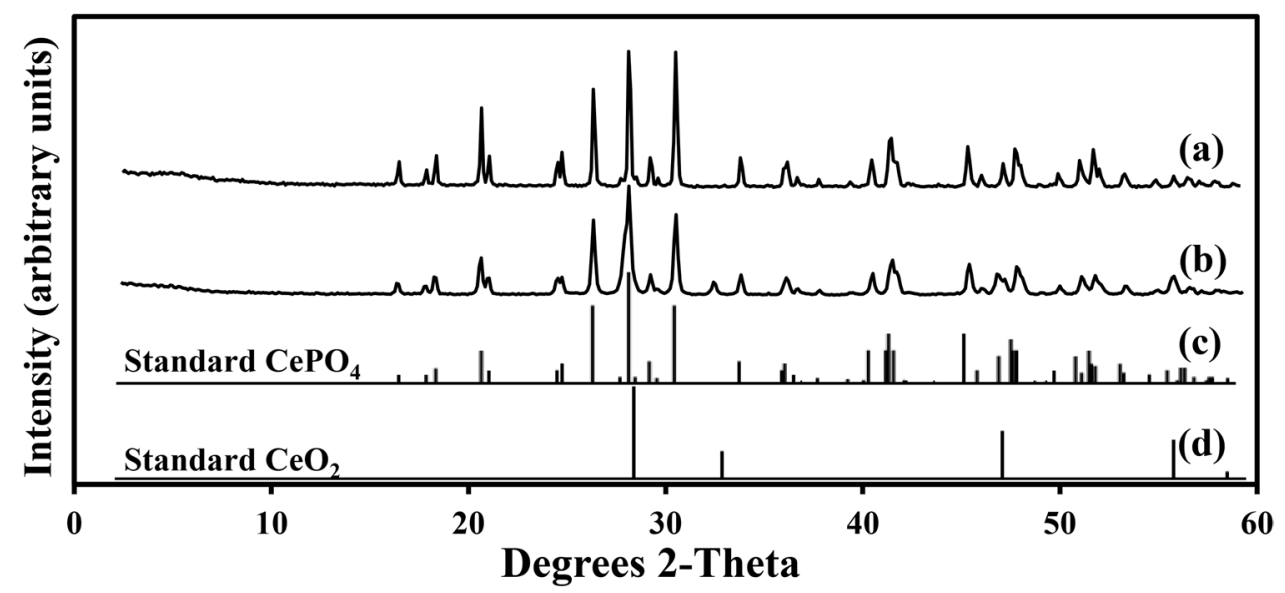

Fig. 7 XRD patterns of the minerals after TG-DTG thermal treatment at $1000{ }^{\circ} \mathrm{C}$. The minerals were formed after mixing $\mathrm{CeCl}_{3}$ with natural struvite leachate for $24 \mathrm{~h}$ at room temperature. (a) Natural struvite leachate with $20 \mathrm{mM} \mathrm{CeCl}_{3}$. (b) Natural struvite leachate with

curve showed two distinct thermal events at $164.7^{\circ} \mathrm{C}$ and $414.7{ }^{\circ} \mathrm{C}$ with a total mass-loss of $19.6 \%$ for the biomineral
$50 \mathrm{mM} \mathrm{CeCl}_{3}$. (c) Standard reference pattern of the mineral $\mathrm{CePO}_{4}$ (PDF card number: 32-199). (d) Standard reference pattern of the mineral $\mathrm{CeO}_{2}$ (PDF card number: 34-394). Typical patterns are shown from one of several determinations

sample formed by the precipitation of natural struvite leachate at $50 \mathrm{mM} \mathrm{CeCl}_{3}$ (Fig. 8B). 
Fig. 8 Thermogravimetric analysis of the biominerals formed by mixing natural struvite leachate with (A) $20 \mathrm{mM}$ and (B) $50 \mathrm{mM} \mathrm{CeCl}_{3}$ for $24 \mathrm{~h}$ under room temperature. Continuous line: TG curves. Broken line: DTG curves. Typical curves are shown from one of several determinations
(A)

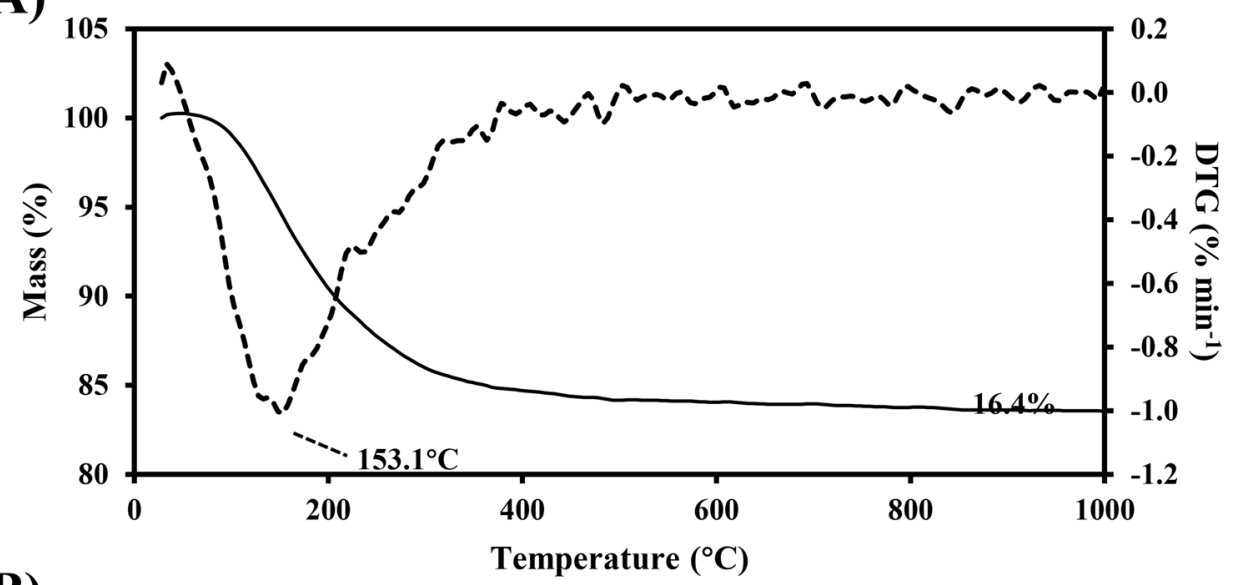

(B)

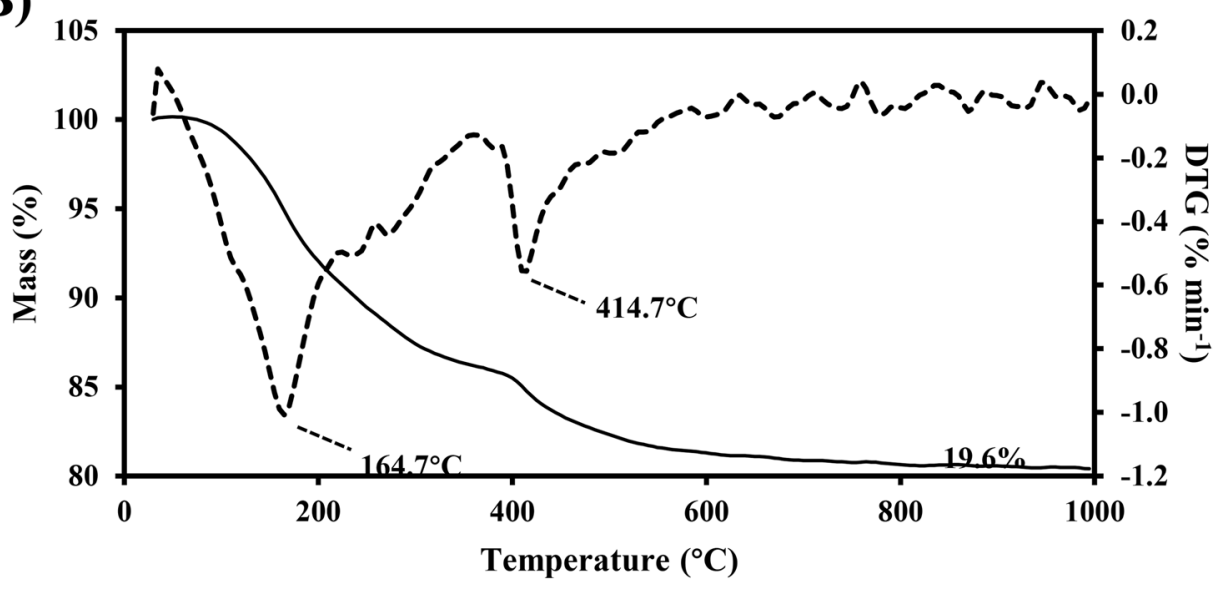

Fig. 9 FTIR spectra of the samples resulting from the reaction of (a) 5 and $20 \mathrm{mM} \mathrm{CeCl}_{3}$ with natural struvite leachate, (b) 40 and $50 \mathrm{mM} \mathrm{CeCl}_{3}$ with natural struvite leachate. Typical spectra are shown from several similar determinations

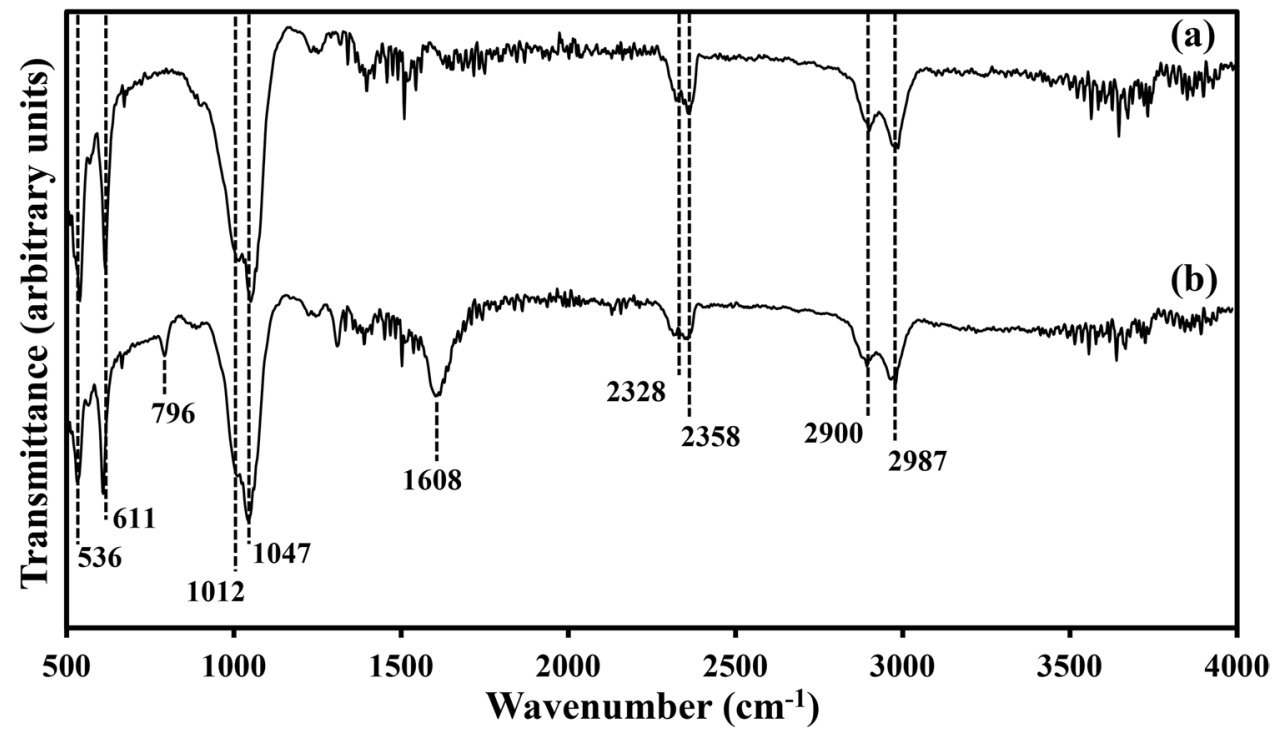

The amorphous biominerals resulting from the reaction of struvite leachate with $5,20,40$ and $50 \mathrm{mM} \mathrm{CeCl}_{3}$ were further analyzed using FTIR. Small and sharp peaks at around 536 and $611 \mathrm{~cm}^{-1}$ and broad peaks at around 1012 and $1047 \mathrm{~cm}^{-1}$ were observed in all samples tested (Fig. 9). Medium-sized peaks at $2328-2358 \mathrm{~cm}^{-1}$ and 
2900-2987 $\mathrm{cm}^{-1}$ were observed for all biomineral samples (Fig. 9). A minute peak at $796 \mathrm{~cm}^{-1}$ and a medium-sized peak at $1608 \mathrm{~cm}^{-1}$ were observable in only the biomineral samples precipitated at higher Ce concentrations (40 and $50 \mathrm{mM} \mathrm{CeCl}$ ) (Fig. 9b).

\section{Discussion}

The natural struvite sample contains a rich source of $\mathrm{P}$, which was completely released after incubation with $A$. niger in liquid MCD medium. The complete dissolution of struvite was caused by acidolysis resulting from fungal-produced oxalic acid $\left(\mathrm{H}_{2} \mathrm{C}_{2} \mathrm{O}_{4}\right)$ (Suyamud et al. 2020; Ferrier et al. 2021). Compared to the struvite-free control, lower amounts of oxalic acid in the struvite-containing groups were due to the consumption of oxalic acid, which can result in the formation of insoluble magnesium oxalate. Interestingly, $A$. niger yielded significantly more biomass and exhibited more luxuriant growth in the medium with natural struvite than without struvite. The growth state of $A$. niger can be affected by nitrogen and phosphorus source, and the presence of trace elements, which contribute greatly to the normal functioning of physiological processes in organisms (Agnihotri 1967). The natural struvite sample contains ammonium from sewage pipes (Kecskésová et al. 2020), which provides an extra nitrogen source for mycelial growth (Gadd 2007). MCD medium only contains basic nutrients and was devoid of trace elements such as $\mathrm{Cu}, \mathrm{Mn}$ and $\mathrm{Zn}$. Besides $\mathrm{Mg}$ and $\mathrm{P}$, the natural struvite sample contains $\mathrm{Ca}, \mathrm{Co}, \mathrm{Fe}$ and $\mathrm{Mn}$, all of which are important trace elements. In other work, A. niger yielded $25 \%$ more biomass in a struvite-free AP1 medium, which contained trace elements, than in a medium amended with $1 \%$ natural and synthetic struvite (Suyamud et al. 2020). Therefore, it appears the presence of ammonium and trace elements in the natural struvite also contributed to the luxuriant growth of $A$. niger. Moreover, the use of medium with minimal components can reduce impurities in the resulting biominerals, which is important for biorecovery purposes.

The quantification experiments showed that more than $99 \%$ of $\mathrm{Ce}^{3+}$ was removed from solution and a large amount of precipitate was formed. The significant decline of $\mathrm{pH}$ was due to the hydrolysis of $\mathrm{Ce}^{3+}$ (Xue et al. 2017) as excessive amounts of $\mathrm{CeCl}_{3}$ were mixed with the biomass-free culture medium. The biominerals precipitated contained a high amount of $\mathrm{P}$ and appeared to be nanoscale amorphous materials with no distinguishable boundaries. Because of this, Rietveld refinement was adopted in association with XRD for a more accurate determination of the mineral phases contained in the materials. The XRD-Rietveld results indicated that small amounts of oxalates were formed at a higher $\mathrm{Ce}^{3+}$ concentration $\left(50 \mathrm{mM} \mathrm{CeCl}_{3}\right)$, which was corroborated by the SEM images that showed large oxalate-like crystals amid an amorphous background at this concentration, thus confirming the occurrence of cerium oxalate decahydrate $\left[\mathrm{Ce}_{2}\left(\mathrm{C}_{2} \mathrm{O}_{4}\right)_{3} \cdot 10 \mathrm{H}_{2} \mathrm{O}\right]$. This also indicated that the Ce phosphate $\left[\mathrm{Ce}\left(\mathrm{PO}_{4}\right) \cdot \mathrm{H}_{2} \mathrm{O}\right]$ biominerals, formed at $20 \mathrm{mM} \mathrm{CeCl}$ using the biomass-free natural struvite culture medium and subsequently transformed into $100 \% \mathrm{CePO}_{4}$, were of high purity and high thermal stability. The presence of $\mathrm{CeO}_{2}$ in the samples after thermal treatment was due to the thermal decomposition of $\mathrm{Ce}_{2}\left(\mathrm{C}_{2} \mathrm{O}_{4}\right)_{3} \cdot 10 \mathrm{H}_{2} \mathrm{O}$ formed at $50 \mathrm{mM}$ $\mathrm{CeCl}_{3}$. The resulting $\mathrm{Na}_{3} \mathrm{Ce}\left(\mathrm{PO}_{4}\right)_{2}$ in the samples after calcination probably arose from $\mathrm{Na}$-containing impurities in the biominerals. One study discovered that $\beta-\mathrm{Na}_{3} \mathrm{Ce}\left(\mathrm{PO}_{4}\right)_{2}$ was an intermediate compound in a $\mathrm{CePO}_{4}-\mathrm{Na}_{3} \mathrm{PO}_{4}$ hydrothermal crystallization system at $950{ }^{\circ} \mathrm{C}$ (Xu et al. 1996). The TG-DTG curves corroborated XRD-Rietveld results in that there was single component in the biominerals precipitated using the natural struvite leachate at $20 \mathrm{mM} \mathrm{CeCl}_{3}$. The mass-loss at $153.1{ }^{\circ} \mathrm{C}$ (precipitation of natural struvite leachate with $20 \mathrm{mM} \mathrm{CeCl}_{3}$ ) can be attributed to the evaporation of water and the dehydration of water of crystallization in $\mathrm{Ce}\left(\mathrm{PO}_{4}\right) \cdot \mathrm{H}_{2} \mathrm{O}$. In the biomineral sample formed using the struvite leachate at $50 \mathrm{mM} \mathrm{CeCl}_{3}$, two thermal decomposition events were recorded, i.e. the one at $164.7^{\circ} \mathrm{C}$ was attributed to the loss of water and the other at $414.7^{\circ} \mathrm{C}$ to the transformation of $\mathrm{Ce}_{2}\left(\mathrm{C}_{2} \mathrm{O}_{4}\right)_{3} \cdot 10 \mathrm{H}_{2} \mathrm{O}$ into $\mathrm{CeO}_{2}$.

FTIR spectroscopy was employed for better identification of functional groups in the amorphous minerals. The characteristic peaks at 536 and $611 \mathrm{~cm}^{-1}$ were due to the $v_{4}$ vibrations of O-P-O bonds (Masui et al. 2003; Li et al. 2018). The absorption band around the strong dual peaks at 1012 and $1047 \mathrm{~cm}^{-1}$ was attributed to the $v_{3}$ vibration modes of O-P-O bonds (Tie et al. 1997; Li et al. 2016). The most conspicuous spectral difference was that the experimental samples showed distinctive peaks at around $2328-2358 \mathrm{~cm}^{-1}$ and $2900-2987 \mathrm{~cm}^{-1}$. The peak around 2328 and $2358 \mathrm{~cm}^{-1}$ is characteristic of $\mathrm{O}=\mathrm{C}=\mathrm{O}$ asymmetric stretching (Bal et al. 2001). The medium-sized band around the double peaks at 2900 and $2987 \mathrm{~cm}^{-1}$ was due to $-\mathrm{CH}_{2}$ and $-\mathrm{CH}_{3}$ (symmetric and asymmetric) stretching from aliphatic groups, possibly arising from saturated fatty acids, lipids and proteins (Georgakopoulos 2003; Lazar et al. 2012; Mecozzi et al. 2012). Similar double-peak patterns over this absorption range were shown for EPS-associated jarosite $\left[\mathrm{KFe}^{3+}{ }_{3}(\mathrm{OH})_{6}\left(\mathrm{SO}_{4}\right)_{2}\right]$, which was biosynthesized by Purpureocillium lilacinum (Bao et al. 2018). The moderate absorption around $1608 \mathrm{~cm}^{-1}$ for biominerals formed at 40 and $50 \mathrm{mM} \mathrm{CeCl}_{3}$ is assigned to the $\mathrm{C}=\mathrm{O}$ stretching of oxalate (Pan and Wang 2017), which again corroborated the XRD-Rietveld results that cerium oxalate was formed at higher Ce concentrations. The FTIR results also implied that the amorphous biominerals were probably precipitated in association with organic matter, as it has been reported 
that extracellular polymeric substances produced by A. niger and Aureobasidium pullulans contain tryptophan-like and aromatic protein-like substances and can have interactions with $\mathrm{Co}, \mathrm{Hg}$, Ni and Se (Yang et al. 2019; Song et al. 2020).

Our results provide a novel approach to the treatment of naturally occurring struvite by fungal-produced oxalic acid. The resulting leachate was able to remove $\mathrm{Ce}^{3+}$ leading to the formation of amorphous biominerals, which were identified as cerium phosphate $\left[\mathrm{Ce}\left(\mathrm{PO}_{4}\right) \cdot \mathrm{H}_{2} \mathrm{O}\right]$ at low Ce concentration and a mixture of cerium phosphate and cerium oxalate $\left[\mathrm{Ce}_{2}\left(\mathrm{C}_{2} \mathrm{O}_{4}\right)_{3} \cdot 10 \mathrm{H}_{2} \mathrm{O}\right]$ at a high $\mathrm{Ce}$ concentration. The phosphate-containing biominerals formed in the natural struvite leachate at $20 \mathrm{mM} \mathrm{CeCl}_{3}$ showed high purity and excellent thermal stability and can be transformed into $\mathrm{CePO}_{4}$ after thermal treatment. This study has provided insights into the biomineralization of REE by fungal-mediated oxalate and phosphate precipitation systems, which have a potential for metal biorecovery, bioremediation and biosynthesis of nanomaterials.

Acknowledgements The authors would like to thank Dr. Yongchang Fan (Materials and Photonics Systems Group, University of Dundee) for assistance with SEM and EDXA, and Thomas Dyer (Civil Engineering, School of Science and Engineering, University of Dundee) for analysis of the Rietveld refinement of XRD data.

Author contribution XK conceived the idea, designed the study, performed most of the experiments, interpreted the data and wrote the manuscript. LC carried out the XRD and TGA analyses and analyzed the resulting data. XG carried out FTIR spectroscopy and processed the resulting data. GMG secured the funding, supervised the project and revised the manuscript. All authors read and approved the manuscript.

Funding GMG receives financial support from the Natural Environment Research Council (NE/M010910/1 (TeaSe); NE/M011275/1 $\left.\left(\mathrm{COG}^{3}\right)\right)$. XK received a joint PhD scholarship from the School of Life Sciences, University of Dundee and China Scholarship Council (No. 201606910077).

Open Access This article is licensed under a Creative Commons Attribution 4.0 International License, which permits use, sharing, adaptation, distribution and reproduction in any medium or format, as long as you give appropriate credit to the original author(s) and the source, provide a link to the Creative Commons licence, and indicate if changes were made. The images or other third party material in this article are included in the article's Creative Commons licence, unless indicated otherwise in a credit line to the material. If material is not included in the article's Creative Commons licence and your intended use is not permitted by statutory regulation or exceeds the permitted use, you will need to obtain permission directly from the copyright holder. To view a copy of this licence, visit http://creativecommons.org/licenses/by/4.0/.

\section{References}

Adeyemi AO, Gadd GM (2005) Fungal degradation of calcium-, leadand silicon-bearing minerals. Biometals 18:269-281
Agnihotri VP (1967) Role of trace elements in the growth and morphology of five ascosporic Aspergillus species. Can J Bot 45:73-79

Babu S, Cho JH, Dowding JM, Heckert E, Komanski C, Das S, Colon J, Baker CH, Bass M, Self WT, Seal S (2010) Multicolored redox active upconverter cerium oxide nanoparticle for bio-imaging and therapeutics. Chem Commun 46:6915-6917

Bal R, Tope B, Das T, Hegde S, Sivasanker S (2001) Alkali-loaded silica, a solid base: investigation by FTIR spectroscopy of adsorbed $\mathrm{CO}_{2}$ and its catalytic activity. J Catal 204:358-363

Bao P, Xia M, Liu A, Wang M, Shen L, Yu R, Liu Y, Li J, Wu X, Fang C, Chen M, Qiu G, Zeng W (2018) Extracellular polymeric substances (EPS) secreted by Purpureocillium lilacinum strain Y3 promote biosynthesis of jarosite. RSC Adv 8:22635-22642

Barrera-Villatoro A, Boronat C, Rivera-Montalvo T, Correcher V, García-Guinea J, Zarate-Medina J (2017) Cathodoluminescence response of natural and synthetic lanthanide-rich phosphates $\left(\mathrm{Ln}^{3+}\right.$ : Ce, Nd). Radiat Phys Chem 141:271-275

Bolan NS, Naidu R, Mahimairaja S, Baskaran S (1994) Influence of low-molecular-weight organic acids on the solubilization of phosphates. Biol Fert Soils 18:311-319

Bu WB, Hua ZL, Chen HR, Zhang LX, Shi JL (2004) Hydrothermal synthesis of ultraviolet-emitting cerium phosphate single-crystal nanowires. Chem Lett 33:612-613

de Lima JF, Serra OA (2013) Cerium phosphate nanoparticles with low photocatalytic activity for UV light absorption application in photoprotection. Dyes Pigments 97:291-296

Dhami NK, Quirin MEC, Mukherjee A (2017) Carbonate biomineralization and heavy metal remediation by calcifying fungi isolated from karstic caves. Ecol Eng 103:106-117

Doyle JD, Parsons SA (2002) Struvite formation, control and recovery. Water Res 36:3925-3940

Ferrier J, Csetenyi L, Gadd GM (2021) Selective fungal bioprecipitation of cobalt and nickel for multiple-product metal recovery. Microb Biotechnol 14:1747-1756

Fomina M, Charnock JM, Hillier S, Alvarez R, Gadd GM (2007) Fungal transformations of uranium oxides. Environ Microbiol 9:1696-1710

Francis AJ (1998) Biotransformation of uranium and other actinides in radioactive wastes. J Alloy Compd 271:78-84

Gadd GM (2007) Geomycology: biogeochemical transformations of rocks, minerals, metals and radionuclides by fungi, bioweathering and bioremediation. Mycol Res 111:3-49

Gadd GM (2010) Metals, minerals and microbes: geomicrobiology and bioremediation. Microbiol 156:609-643

Gadd GM (2017) The geomycology of elemental cycling and transformations in the environment. Microbiol Spectr 5:1-16

Georgakopoulos A (2003) Study of low rank Greek coals using FTIR spectroscopy. Energ Source 25:995-1005

Hanhoun M, Montastruc L, Azzaro-Pantel C, Biscans B, Frèche M, Pibouleau L (2011) Temperature impact assessment on struvite solubility product: a thermodynamic modeling approach. Chem Eng J 167:50-58

Haque N, Hughes A, Lim S, Vernon C (2014) Rare earth elements: overview of mining, mineralogy, uses, sustainability and environmental impact. Resources 3:614

Hernández Jiménez JE, Nyiraneza J, Fraser TD, Peach Brown HC, Lopez-Sanchez IJ, Botero-Botero LR (2020) Enhancing phosphorus release from struvite with biostimulants. Can J Soil Sci 100:1-11

Hogendoorn C, Roszczenko-Jasińska P, Martinez-Gomez NC, de Graaff J, Grassl P, Pol A, Camp HJMOD, Daumann LJ (2018) A facile Arsenazo III based assay for monitoring rare earth element depletion from cultivation media of methanotrophic and methylotrophic bacteria. Appl Environ Microb 84:e02887-e2917 
Kecskésová S, Imreová Z, Martonka M, Drtil M (2020) Chemical dissolution of struvite precipitates in pipes from anaerobic sludge digestion. Chem Pap 74:2545-2552

Kang X, Csetenyi L, Gadd GM (2020) Monazite transformation into $\mathrm{Ce}-$ and La-containing oxalates by Aspergillus niger. Environ Microbiol 22:1635-1648

Kang,X, Csetenyi L, Gadd GM (2021) Colonization and bioweathering of monazite by Aspergillus niger: solubilization and precipitation of rare earth elements. Environ Microbiol (in press)

Kirtzel J, Ueberschaar N, Deckert-Gaudig T, Krause K, Deckert V, Gadd G, Kothe E (2020) Organic acids, siderophores, enzymes and mechanical pressure for black slate bioweathering with the basidiomycete Schizophyllum commune. Environ Microbiol 22:1535-1546

Kumari A, Panda R, Jha MK, Kumar JR, Lee JY (2015) Process development to recover rare earth metals from monazite mineral: a review. Miner Eng 79:102-115

Kumari D, Qian X-Y, Pan X, Achal V, Li Q, Gadd GM (2016) Microbially-induced carbonate precipitation for immobilization of toxic metals. Adv Appl Microbiol 94:79-108

Lazar G, Ureche D, Ifrim IL, Stamate M, Ureche C, Nedeff V, Nistor ID, Finaru AL, Lazar IM (2012) Effects of the environmental stress on two fish populations revealed by statistical and spectral analysis. Environ Eng Manag J 11:109-124

Le Corre KS, Valsami-Jones E, Hobbs P, Parsons SA (2009) Phosphorus recovery from wastewater by struvite crystallization: a review. Crit Rev Env Sci Tec 39:433-477

Li Q, Csetenyi L, Gadd GM (2014) Biomineralization of metal carbonates by Neurospora crassa. Environ Sci Technol 48:14409-14416

Li Q, Liu D, Wang T, Chen C, Gadd GM (2020) Iron coral: novel fungal biomineralization of nanoscale zerovalent iron composites for treatment of chlorinated pollutants. Chem Eng J 402:126263

Li Q, Liu J, Gadd GM (2020b) Fungal bioremediation of soil cocontaminated with petroleum hydrocarbons and toxic metals. Appl Microbiol Biot 104:8999-9008

Li Q, Liu D, Jia Z, Csetenyi L, Gadd GM (2016) Fungal biomineralization of manganese as a novel source of electrochemical materials. Curr Biol 26:950-955

Li Y, Fu Q, Flytzani-Stephanopoulos M (2000) Low-temperature water-gas shift reaction over $\mathrm{Cu}$-and $\mathrm{Ni}$-loaded cerium oxide catalysts. Appl Catal B-Environ 27:179-191

Li Z, Su M, Duan X, Tian D, Yang M, Guo J, Wang S, Hu S (2018) Induced biotransformation of lead (II) by Enterobacter sp. in $\mathrm{SO}_{4}-\mathrm{PO}_{4}-\mathrm{Cl}$ solution. J Hazard Mater 357:491-497

Liang X, Csetenyi L, Gadd GM (2016a) Uranium bioprecipitation mediated by yeasts utilizing organic phosphorus substrates. Appl Microbiol Biot 100:5141-5151

Liang X, Gadd GM (2017) Metal and metalloid biorecovery using fungi. Microb Biotechnol 10:1199-1205

Liang X, Hillier S, Pendlowski H, Gray N, Ceci A, Gadd GM (2015) Uranium phosphate biomineralization by fungi. Environ Microbiol 17:2064-2075

Liang X, Kierans M, Ceci A, Hillier S, Gadd GM (2016b) Phosphatase-mediated bioprecipitation of lead by soil fungi. Environ Microbiol 18:219-231

Liang X, Perez MAM, Nwoko KC, Egbers P, Feldmann J, Csetenyi L, Gadd GM (2019) Fungal formation of selenium and tellurium nanoparticles. Appl Microbiol Biotechnol 103:7241-7259

Liu F, Csetenyi L, Gadd GM (2019) Amino acid secretion influences the size and composition of copper carbonate nanoparticles synthesized by ureolytic fungi. Appl Microbiol Biot 103:7217-7230
Liu F, Shah DS, Gadd GM (2021) Role of protein in fungal biomineralization of copper carbonate nanoparticles. Curr Biol $31: 358-368$

Martínez-Arias A, Hungría AB, Fernandez-Garcia M, Iglesias-Juez A, Conesa J, Mather G, Munuera G (2005) Cerium-terbium mixed oxides as potential materials for anodes in solid oxide fuel cells. J Power Sources 151:43-51

Massari S, Ruberti M (2013) Rare earth elements as critical raw materials: focus on international markets and future strategies. Resour Policy 38:36-43

Masui T, Hirai H, Imanaka N, Adachi G (2003) Characterization and thermal behavior of amorphous cerium phosphate. Phys Status Solidi A 198:364-368

Mecozzi M, Pietroletti M, Scarpiniti M, Acquistucci R, Conti ME (2012) Monitoring of marine mucilage formation in Italian seas investigated by infrared spectroscopy and independent component analysis. Environ Monit Assess 184:6025-6036

Mendes de GO, Bahri-Esfahani J, Csetenyi L, Hillier S, George T, Gadd GM (2021) Chemical and physical mechanisms of fungal bioweathering of rock phosphate. Geomicrobiol J 38:384-394

Mendes G de O, Dyer T, Csetenyi L, Gadd GM (2021b) Rock phosphate solubilization by abiotic and fungal produced oxalic acid: reaction parameters and bioleaching potential. Microbial Biotechnol (in press)

Mooney RC (1950) X-ray diffraction study of cerous phosphate and related crystals. I Hexagonal Modification Acta Crystallogr $3: 337-340$

Moss RL, Tzimas E, Willis P, Arendorf J, Thompson P, Chapman A, Morley N, Sims E, Bryson R, Pearson J, Tercero Espinoza L, Marscheider-Weidemann F, Soulier M, Lüllmann A, Sartorius C, Ostertag K (2013) Critical metals in the path towards the decarbonisation of the EU energy sector. Assessing rare metals as supply-chain bottlenecks in low-carbon energy technologies. JRC Scientific and Policy Reports, Report EUR 25994 EN. Joint Research Centre, Ispra

Pan Y, Wang D (2017) Fabrication of low-fire-hazard flexible poly (vinyl chloride) via reutilization of heavy metal biosorbents. J Hazard Mater 339:143-153

Rawlings DE, Dew D, du Plessis C (2003) Biomineralization of metal-containing ores and concentrates. Trends Biotechnol 21:38-44

Rhee YJ, Hillier S, Gadd GM (2016) A new lead hydroxycarbonate produced during transformation of lead metal by the soil fungus Paecilomyces javanicus. Geomicrobiol J 33:250-260

Singh KR, Nayak V, Sarkar T, Singh RP (2020) Cerium oxide nanoparticles: properties, biosynthesis and biomedical application. RSC Adv 10:27194-27214

Siposova K, Huntosova V, Shlapa Y, Lenkavska L, Macajova M, Belous A, Musatov A (2019) Advances in the study of cerium oxide nanoparticles: new insights into antiamyloidogenic activity. ACS Appl Bio Mater 2:1884-1896

Song W, Yang Y, Liang X, Liu F, Gadd GM (2020) Influence of metals and metalloids on the composition and fluorescence quenching of the extracellular polymeric substances produced by the polymorphic fungus Aureobasidium pullulans. Appl Microbiol Biot 104:7155-7164

Suyamud B, Ferrier J, Csetenyi L, Inthorn D, Gadd GM (2020) Biotransformation of struvite by Aspergillus niger: phosphate release and magnesium biomineralization as glushinskite. Environ Microbiol 22:1588-1602

Tang C, Bando Y, Golberg D, Ma R (2005) Cerium phosphate nanotubes: synthesis, valence state, and optical properties. Angew Chem 117:582-585 
Tie S, Li Y, Yang YS (1997) Structure and vibration spectra of new pseudo-pyrophosphate $\mathrm{NaDyP}_{2} \mathrm{O}_{7}$. J Phys Chem Solids 58:957-961

van Krevel J, van Rutten J, Mandal H, Hintzen H, Metselaar R (2002) Luminescence properties of terbium-, cerium-, or europiumdoped $\alpha$-sialon materials. J Solid State Chem 165:19-24

Verrecchia EP, Dumont JL, Verrecchia KE (1993) Role of calcium oxalate biomineralization by fungi in the formation of calcretes; a case study from Nazareth, Israel. J Sediment Res 63:1000-1006

Wang X, Selvam A, Lau SS, Wong JW (2018) Influence of lime and struvite on microbial community succession and odour emission during food waste composting. Bioresource Technol 247:652-659

Xing Y, Li M, Davis SA, Mann S (2006) Synthesis and characterization of cerium phosphate nanowires in microemulsion reaction media. J Phys Chem B 110:1111-1113

Xu X, Hao R, Xu H, Lu A (2020) Removal mechanism of Pb(II) by Penicillium polonicum: immobilization, adsorption, and bioaccumulation. Sci Rep-UK 10:9079
Xu Y, Feng S, Pang W (1996) Hydrothermal synthesis and characterization of $\beta-\mathrm{Na}_{3} \mathrm{Ce}\left(\mathrm{PO}_{4}\right)_{2}$. Mater Lett 28:313-315

Xue S, Wu W, Bian X, Wu Y (2017) Dehydration, hydrolysis and oxidation of cerium chloride heptahydrate in air atmosphere. J Rare Earth 35:1156-1163

Yang Y, Song W, Ferrier J, Liu F, Csetenyi L, Gadd GM (2019) Biorecovery of cobalt and nickel using biomass-free culture supernatants from Aspergillus niger. Appl Microbiol Biot 104:417-425

Zhenghua W, Xiaorong W, Yufeng Z, Lemei D, Yijun C (2001) Effects of apatite and calcium oxyphosphate on speciation and bioavailability of exogenous rare earth elements in the soil-plant system. Chem Spec Bioavailab 13:49-56

Publisher's note Springer Nature remains neutral with regard to jurisdictional claims in published maps and institutional affiliations. 